\title{
Efektivitas Media Online Bagi Pendidikan \\ Di Era Covid-19
}

\author{
${ }^{1}$ Apriani Harahap, ${ }^{2}$ Anita Dwiana Nasution, ${ }^{3}$ Fikri Ismail \\ ${ }^{1,2,3}$ Universitas Islam Negeri Sumatera Utara
}

\begin{abstract}
ABSTRAK
Penelitian ini dilatarbelakangi oleh penanganan masalah dari dampak pandemic covid-19. Yang dimana dunia pendidikan juga harus melakukan metode pendidikan yang berbeda dengan sebelum adanya covid-19 ini yaitu melaksanakan metode pembelajaran melalui Media Online. Tujuan dari penelitian ini adalah seberapa efektifitas media online bagi pendidikan di Era Covid ini yang digunakan selama perkuliahan oleh Dosen dan Mahasiswa. Sampel dari penelitian ini sebanyak 25 mahasiswa dari beberapa universitas dan jurusan yang berbeda-beda, objeknya adalah dunia pendidikan. Metode yang digunakan di penelitian ini adalah Kuantitatif Pre Eksperimental, dapat diartikan sebagai penelitian yang mendekati eksperimen atau bisa disebut eksperimen semu yang dimana jenis desain yang digunakan adalah jenis Angket yaitu suatu jenis teknik yang digunakan untuk mengetahui respon objek mengenai yang diteliti untuk mendapatkan hasil penelitian.
\end{abstract}

Kata kunci : Media; Online; Hasil Belajar; Pendidikan; Covid-19.

\section{PENDAHULUAN}

Dalam penanganan masalah dari dampak pandemi Covid-19 pada dunia pendidikan, seluruh steakholder harus saling membantu dan bekerja sama. Sekolah lembaga harus menyelenggarakan pendidikan dan siap siaga memfasilitasi perubahan apapun yang menyangkut pendidikan siswanya (Hasan, Muhammad 2020). Pendidikan yang merupakan tanggung jawab bersama yaitu : Guru, Keluarga, lingkungan kita berada dan Pemerintah, di lihat dari sudut pandang berbangsa dima menjungjung 
tinggi Demokrasi (Soemanto 2003). Pendidikan etika juga pada masa Digital ini sangat diperlukan mengingat apa yang ada di dalam Internet dapat di akses jika tidak mendapatkan pendidikan etika maka akan berdampak buruk. Penekanan belajar di rumah kepada siswa agar mendapatkan pengawasan dari orangtua dan keluarga, supaya tenaga pendidik memberikan pengajaran yang baik dan mampu memberikan pengajaran yang baik supaya peserta didik dapat menerima pelajaran tersebut (Hasan, Muhammad 2020).

Mengingat kita sedang masa pandemi E-learning juga sangat di butuhkan di kalangan masyarakat di masa sekarang ini. Menggunakan Elearning dapat memberikan metode belajar-mengajar dengan hemat dan aman di masa Pandemi ini. selain itu, menggunakan E-learning juga bisa memberikan rasa kepercayaan terhadap diri peserta didik dan juga dapat memberikan kemandirian bagi masyarakat. (Wantiknas 2020). Di Era digital ini telah membawa dampak yang cukup besar dalam kehidupan masyarakat. Masyarakat seolah-olah dipaksa untuk "berimigrasi" dari cara manual ke media digital dalam menjalani kehidupan mereka, salah satunya adalah dalam sektor pendidikan.

Pada masa pandemi ini juga sudah mengubah tingkah laku seharian di seluruh orang di dunia, orang-orang disarankan untuk menjaga jarak dan membatasi perjalanan sesering mungkin. Hal ini juga berlaku dalam dunia pendidikan, pendidikan online sebagai tanggapan terhadap pandemi Covid-19, pendidikan online telah dilaksanakan dibeberapa sekolah tetapi tergantung status sekolah mereka. Karena pengajaran melalui media online sangat darurat hingga dioperasikan untuk sementara waktu tanpa desain kelas yang direncanakan tidak seperti pembelajaran offline yang ada, baik guru maupun peserta didik sangat mengalami kesulitan beradaptasi dengannya. Untuk itu dari 
dampak pandemi ini menggunakan media online memiliki berbagai keuntungan dan disamping tersebut memiliki beberapa kekurangan dari pembelajaran jarak jauh tersebut (Handayani 2020).

Proses belajar mengajar online kala ini dapat memberikan dampak perbedaan dalam bentuk kognitif (nalar, mengerti dan pengguanan Informasi) bertambahnya nilai ( Individu, Pendidikan, cara berpikir, kemasyarakatan dan professional) juga dalam pememilihan dan penerima dalam sadar nilai, prilaku, penghormatan dan rasa, juga keinginan dalam melakukan perbuatan sadar dan tidak sadar. (FIP-UPI 2007)

Pada masa Pandemi ini Covid telah mengubah gaya hidup orang eluruh dunia, orang-orang disarankan untuk menjaga jarak dan membatasi perjalanan sesering mungkin. Hal ini juga berlaku dalam dunia pendidikan, pendidikan online sebagai tanggapan terhadap pandemic Covid-19 . Agar tercapainya tujuan Pendidikan online ini dengan baik tenaga pendidik juga harus melihat kondisi dan kelayakan peserta didiknya. Agar dapat memberikan bahan ajar dan tugas bisa di pahami oleh peserta didik agar dapatnya berjalan dengan baik kegiatan Belajar-mengajar ini. Sehingga jika sudah kembalinya normal keadaan setelah masa pandemic dapat memberikan efek yang baik bagi peserta didik baik mengenai Ilmu yang di dapatkan dan tingkah laku yang baik juga.

\section{METODE PENELITIAN}

Metode yang akan digunakan dalam penelitian ini adalah Kuantitatif Pre Eksperimental, dapat diartikan sebagai penelitian yang mendekati eksperimen atau bisa disebut eksperimen semu yang dimana jenis desain yang digunakan adalah jenis Angket yaitu suatu jenis teknik yang digunakan untuk mengetahui respon objek mengenai yang diteliti 
untuk mendapatkan hasil penelitian (Sugiyono 2015). Melihat dari suatu kondisi di masa pandemi ini pendidikan merupakan hal yang penting yang harus di teliti sehingga peneliti mengambil Objek penelitiannya adalah Dunia Pendidikan.

Menurut (Suharsimi 2006) bahwa yang dimaksud subjek penelitian adalah sesuatu sumber dari mana data itu dapat diperoleh. Subjeknya dapat berupa Manusia, gerak, benda, tempat ataupun symbol. Bisa disimpulkan bahwa subjek penelitian itu merupakan hal yang terpenting dalam penelitian. Populasi dari penelitian ini adalah 40 Mahasiswa sedangkan orang yang bersedia untuk mengisi survey sebanyak 25 Mahasiswa yang menjadikannya sebagai sampel dari penelitian ini. Penelitian ini melibatkan kurang lebih 25 Mahasiswa yang mempunyai dampak media online di masa pandemi ini dengan mengumpulkan jawaban dari angket yang dibagikan dengan menggunakan media online (Link Survey). Setelah mendaptkan hasil dari angekt yang dibagiakan peneliti dapat menentukan seberapa efeltifitas media online tersebut bagi pendidikan di Era Covid-19.

\section{HASIL PENELITIAN DAN PEMBAHASAN}

Menurut istilah, keefektifan berasal dari kata efektive "yaitu keadaan berpengaruh", sedangkan menurut kamus besar bahasa Indonesia "efektif" adalah "dapat mendapatkan hasil atau keberhasilan.”(Departemen Pendidikan Nasional 2005) Keefektifan belajar menggunakan media online di Era covid-19 ini dapat dilihat dari hasil survey yang sudah dibagikan kepada mahasiswa Setelah membagikan survey di dapatkanlah hasil dari beberapa pertanyaan yang di ajukan kepada Masiswa mengenai kegiatan pembelajaran menggunakan media online diketahui bahwa IP Mahasiswa sebanyak 10 
orang mengalami kenaikan dibandingkan semester yang lalu sebelum terjadinya Pandemi hal tersebut dapat dilihat dari Gambar 1 yang dimana di dalam diagram menggambarkan bahwa sebanyak $40 \%$, Nilai IP Mahasiswa yang turun dari sebelum pandemi ke masa pandemi sebanyak 4 orang yang dimana jika di lihat dari Gambar 1 di dalam diagram sebanyak $16 \%$ dan sedangkan IP yang tetap Normal tidak naik maupun Turun dari saat masa pandemi sebanyak 11 orang atau sebanyak 44 , data dapat dilihat pada gambar 1.

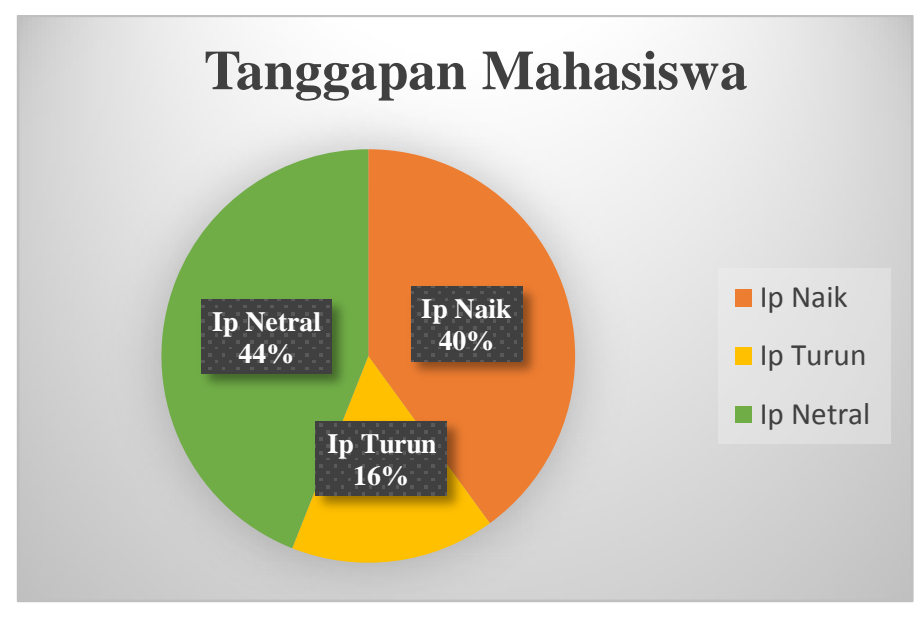

Gambar 1. Aspek Perbandingan Nilai IP sebelum dan saat terjadinya Era Covid-19

Sebelum adanya pandemi dosen dan mahasiswa sudah mempelajari dan mampu menggunakan Media Online oleh karna itu disaat diterapkannya Kuliah melalui Media Online Dosen dan Mahasiswa tidak merasa kesulitan dalam penggunaannya. Terdapat 11 Mahasiswa dari Gambar 2 di dalam Diagram $44 \%$ setuju bahwa mahasiswa dan 
Dosen dapat menjalankan Media Online dengan baik sehingga tidak di dapati kendala pembelajaran melalui Media Online ini.

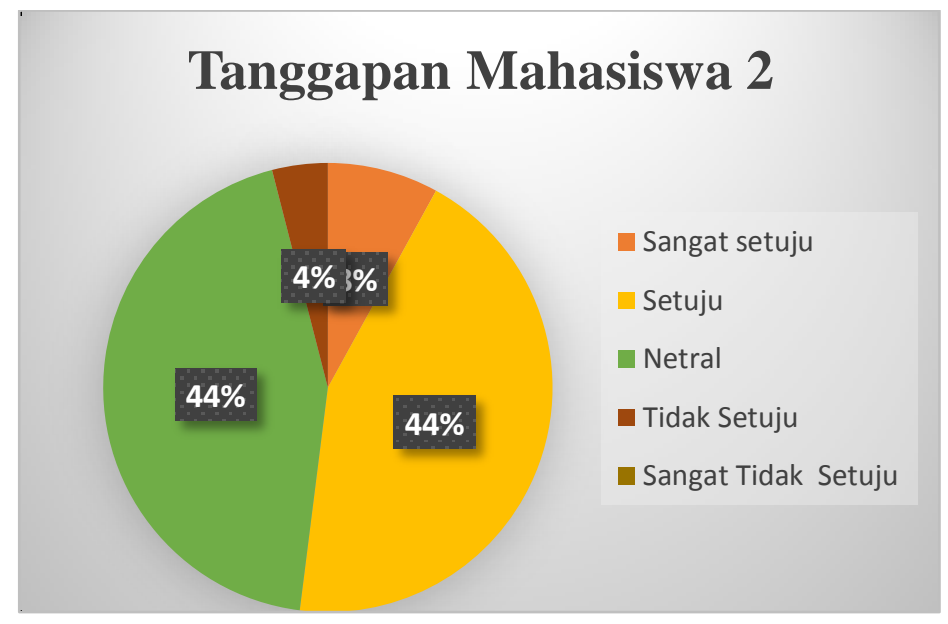

Gambar 2. Aspek Respon Mahasiswa Mengenai Penggunaan Media Online Saat Perkuliahan Di Masa Pandemi

Selama masa pandemi ini semua orang harus bisa menyesuaiakan diri dengan kebiasaan baru yaitu harus melakukan aktiftas di dalam rumah alah satunya yang mengharuskan tidak melakukan pembelajaran tatap muka secara langsung di dalam kelas tetapi melakukan pembelajaran dengan Online. Pelaksanaan perkuliahan melalui media online tentunya ada perbedaan dengan perkuliahan tatap muka yang dimana di dalamnya membutuhkan penyesuaian diri. Dosen harus bisa menyesuaikan pembelajaran yang disampaikan melalui media online tersebut. Tentunya tenaga pengajar (Dosen) harus bisa melaksanakan tugas nya dengan baik dengan menyediakan bahan ajar yang sesuai dengan karakteristik mata kuliah yang diajarkan kepada Mahasiswanya. Dosen harus bisa menyesuaikan pembelajaran yang disampaikan melalui 
media online tersebut. Jika di lihat dari hasil survey yang dimana 11 Mahasiswa menjawab Netral tidak adanya perbedaan dari penyedian bahan ajar melalui Media Online dengan penyampaian pembelajaran di saat kuliah tatap muka bisa di lihat di dalam Gambar 3 di dalam diagram terdapat $44 \%$ menjawab Netral.

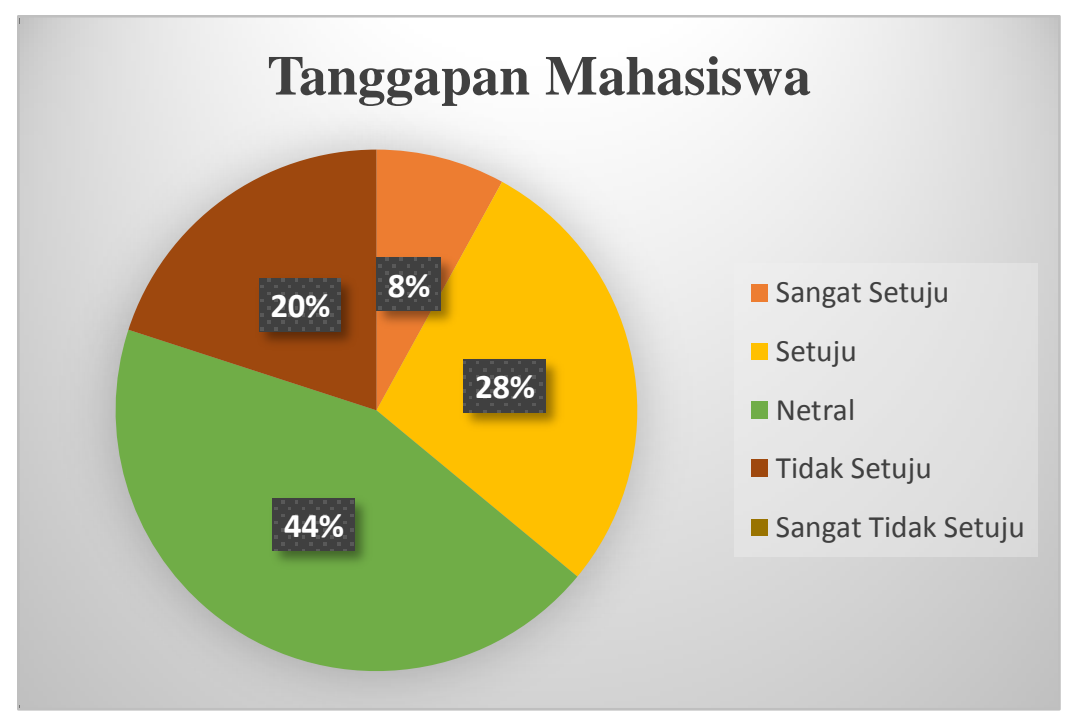

Gambar 3. Aspek Respon Mahasiswa Mengenai Penggunaan Media Online Saat Perkuliahan Di Masa Pandemi

Menurut penelitian dari (Sulisworo 2017) mengatakan bahwa pembelajaran Online dapat meningkatkan motivasi belajar siswa dan akan meningkatkan pemahaman siswa. Pernyataan tersebut tidak seuai jika dilihat dari hasil Survey yang dimana 20 Mahasiswa menjawab bahwa mereka setuju motivasi belajar mereka lebih rendah dibandingkan di saat tatap muka jika dilihat dari Gambar 4 di dalam diagram $80 \%$ mereka setuju bahwa motivasi belajar mereka lebih rendah di saat menggunakan Media Online dibandingkan dengan tatap muka. 
Setiap orang itu tentunya memiliki perbedaan tingkat dalam memahami setiap pembelajaran dan cara agar mereka dapat mamahami suatu pembelajaran. Jika dilihat dari sisi metode pembelajaran di saat pandemi ini di haruskan bahwa pendidikan harus menggunakan Media Online tidak seperti saat sebelum pandemi dengan metode tatap muka. Jika kita lihat dari penemuam dalam penelitian (Istiqomah, Werdhiana, and Wahyono 2017) yang menyatakan bahwa pembelajaran dengan Online dapat meningkatkan pemahaman peserta didik yang terdapat di berbagai jenjang sekolah dan berbagai materi. Penemuan dalam penelitian tersebut tidak sesuai dengan hasil Survey yang sudah dilaksanakan dari beberapa Mahasiswa yang dimana 10 Mahasiswa berpendapat bahwa metode pembelajaran melalui Online dan tatap muka sama saja (Netral) dapat dilihat dari Gambar 5 di dalam diagram $40 \%$ sedangkan yang setuju hanya sebanyak 7 orang jika dilihat dalam diagram hanya $20 \%$.

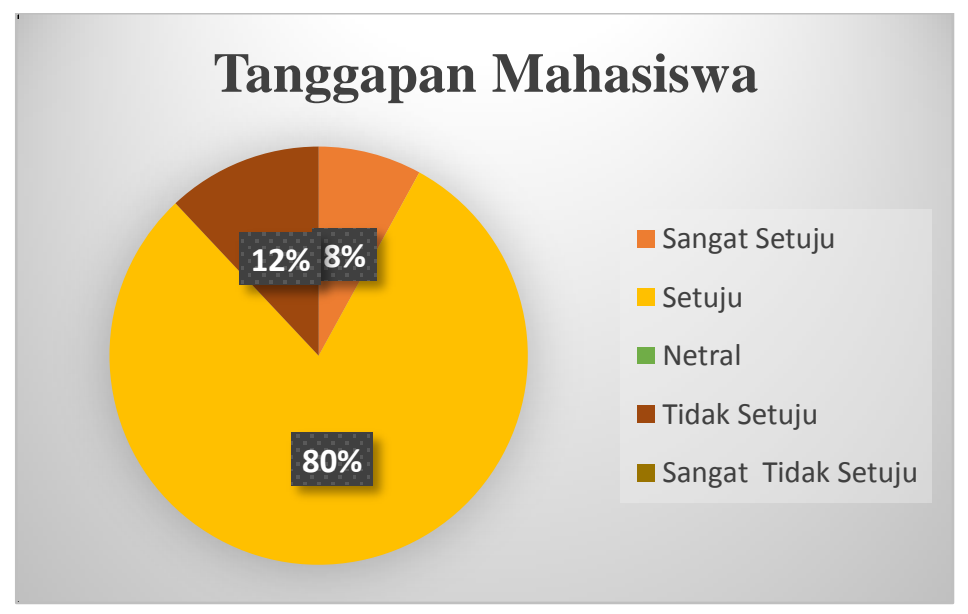

Gambar 4. Aspek Motivasi Belajar Mahasiswa Saat Menggunakan Media Online 


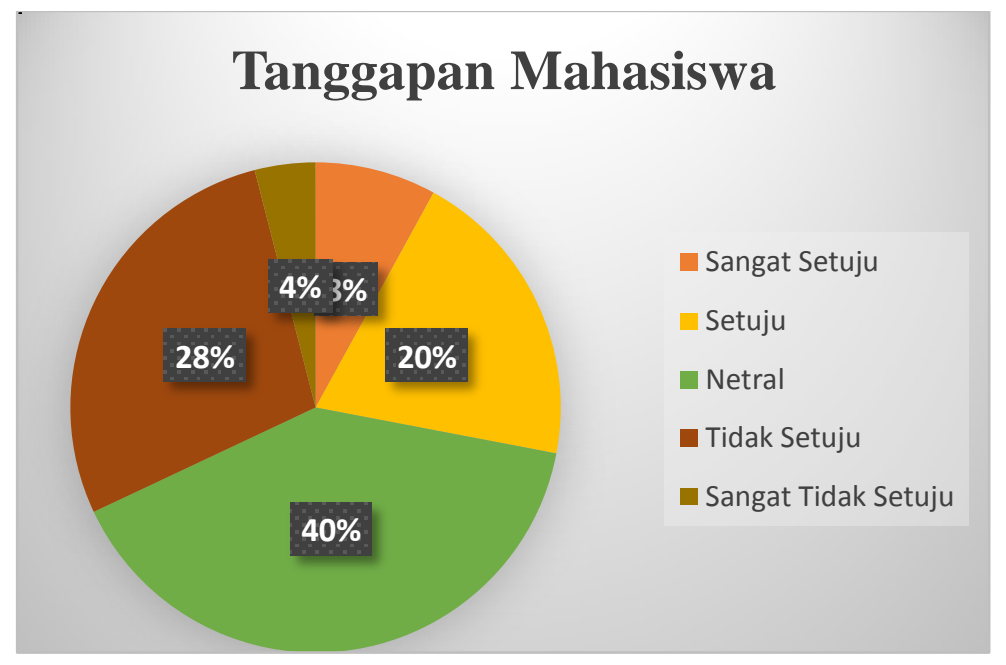

Gambar 5. Aspek Pemahaman Mahasiswa Terkait Materi Yang Diberikan Dengan Media Online

\section{KESIMPULAN}

Hasil penelitian ini jika dikaji dari penggunaan Media Online ini dapat dikuasai dengan baik oleh Dosen dan Mahasiswa karna di saat melakukan kuliah dapat berjalan dengan baik tidak ditemukannya kesulitan dalam penggunaan seperti zoom meeting atau google meet yang dapat dikuasai. Tetapi jika di bahas dari segi motivasi belajar dari Mahasiswa sangatlah rendah dikarenakan dari beberapa faktor. Berdasarkan penelitian tersebut dapat disimpulkan bahwa kurangnya sarana dalam menunjang yang dapat membantu kelancaran dan minat belajar Mahasiswa. Hal tersebutlah yang menjadikan Mahasiswa memiliki motivasi yang redah terhadap minat belajar. Pemahaman mengenai pembelajaran mata kuliah yang disampaikan dosen baik di saat kuliah tatap muka maupun kuliah melalui media online mahasiswa berpendapat bahwa menggunakan metode pembelajaran kedua-duanya 
sama-sama dapat memahaminya atau merasa Netral. Sehingga hasil dari data penelitian melalui angket yang dibagikan respon mahasiswa mengenai pemahaman disaat pembelajaran menjawab $40 \%$ Netral dan yang menjawab mengenai kurang memahami hanya menjawab $20 \%$. Dari hasil yang penelitian mengenai Efektifitas media online bagi pendidikan di Era Covid-19 ini dapat disimpulkan bahwa sangat bermanfaat sekali bagi pendidikan dan tidak di dapatkannya hambatanhambatan yang mengakibatkan pembelajaran di saat perkuliahan tidak dapat terlaksana tetapi dapat berjalan dengan baik dan efektif.

\section{DAFTAR REFERENSI}

Departemen Pendidikan Nasional. 2005. "Arti Kata Judi - Kamus Besar Bahasa Indonesia (KBBI) Online.” Balai Pustaka.

FIP-UPI, Tim pengembangan ilmu pendidikan. 2007. Ilmu Dan Aplikasi Pendidikan. PERTAMA. Pt. Imperial Bhakti Utama.

Handayani, Lina. 2020. "Keuntungan , Kendala Dan Solusi Pembelajaran Online Selama Pandemi Covid-19: Studi Ekploratif Di SMPN 3 Bae Kudus Lina Handayani." Journal Industrial Engineering \& Management Research.

Hasan, Muhammad, Dkk. 2020. Perubahan Paradigma Pendidikan Dan Ekonoi Di Masa Pandemi Covid-19. 1st ed. ed. Muhammad Hasan. cijerah kota bandung jawa barat.

Istiqomah, Puput, I Komang Werdhiana, and Unggul Wahyono. 2017. "Pengaruh Penggunaan Media Video Terhadap Peningkatan Pemahaman Konsep Suhu Dan Kalor Pada Siswa Kelas X Man 1 Palu.” JPFT (Jurnal Pendidikan Fisika Tadulako Online).

Soemanto, Wasty. 2003. Psikologi Pendidikan. baru. rineka cpta.

Sugiyono. 2015. Metode Penelitian Pendidikan (Pendekatan Kuantitatif, 
Kualitatif, dan R\&D) Metode Penelitian Pendidikan. Bandung.

Suharsimi, Arikunto. 2006. "Prosedur Penelitian Suatu Pendekatan Praktik." Jakarta: Rineka Cipta.

Sulisworo, D. 2017. "Dampak Pembelajaran E-Learning Terhadap Motivasi Pada Pembelajaran Fisika Di Sekolah Kejuruan.” 9: 1.

Wantiknas. 2020. "Empat Kelebihan Dan Kekurangan Dalam Menerapkan E-Learning."

Zain, Syaiful Bahri Djamarah dan Aswan. 2006. "Strategi Belajar Mengajar. Jakarta: PT Rineka Cipta." Syaiful Bahri Djamarah dan Aswan Zain 